\title{
Identification, Quantification and In-Vitro Genotoxicity of Major Polyaromatic Hydrocarbons Produced by Sugarcane Fly Ash Emitted from Sugarmill
}

\author{
Akanksha Verma, Ramovatar Meena, Anurag Maurya, Usha Singh Gaharwar, Paulraj Rajamani* \\ School of Environmental Sciences, Jawaharlal Nehru University, New Delhi, India \\ Email: vermaakanksha30@gmail.com, *paulrajr@yahoo.com
}

How to cite this paper: Verma, A., Meena, R., Maurya, A., Gaharwar, U.S. and Rajamani, P. (2019) Identification, Quantification and In-Vitro Genotoxicity of Major Polyaromatic Hydrocarbons Produced by Sugarcane Fly Ash Emitted from Sugarmill. Journal of Environmental Protection, 10, 1244-1261.

https://doi.org/10.4236/jep.2019.1010074

Received: August 28, 2019

Accepted: October 6, 2019

Published: October 9, 2019

Copyright $\odot 2019$ by author(s) and Scientific Research Publishing Inc. This work is licensed under the Creative Commons Attribution International License (CC BY 4.0).

http://creativecommons.org/licenses/by/4.0/

\begin{abstract}
Sugarcane burning during harvest and non-harvest season emits various pollutants like volatile organic compounds (VOCs), alkanes, and PAHs (Polyaromatic hydrocarbons) in the surrounding environment. Among these pollutants, PAHs are of uttermost concern due to their high level of toxicity. Burning of sugarcane bagase in sugar mill results in the production of fly ash. Fly ash is produced as a result of sugarcane bagasse burning in sugar mills. In present study, fly ash that comes out from the sugar mill chimney was collected from Western Uttar Pradesh, India and used for further analysis. High temperature and incomplete combustion inside chimney lead to the formation of PAHs. Extraction of PAHs present in fly ash samples was done by ultrasonication method and was identified with GC-FID (gas chromatography-flame ionization detector). Results exhibit the presence of eight PAHs in fly ash samples where the Benzo(a)pyrene and Naphthalene were found to be in high concentration. Furthermore, we have evaluated toxic effects of fly ash and Polyaromatic hydrocarbons (Standard of BaP \& Nap) through different methods i.e. MTT, ROS and comet assay. Significant reduction $(\mathrm{p}<0.001)$ in cell viability was noted in cells treated with fly ash as compared to control. Fly ash samples were also found to induce significant oxidative stress in HeLa cells, which ultimately causes DNA damage. Therefore, it may be concluded that the fly ash samples are toxic to the environment due to the presence of PAHs. Hence, the present study plays an important role in determining the harmful effects of PAHs and their source of occurrence.
\end{abstract}

\section{Keywords}

Sugarcane Fly Ash, Polyaromatic Hydrocarbons, Reactive Oxygen Species 
(ROS), DNA Damage, Environmental Toxicity

\section{Introduction}

India is the second largest producer of sugarcane (341,200 TMT) after Brazil (739,267 TMT harvest) [1]. In India, Maharashtra and Uttar Pradesh are the leading states in terms of sugarcane production. Sugar industries in Uttar Pradesh are one of the largest sugar industries in the Indian economy. Currently, there are 28 sugar mills in Uttar Pradesh, out of which 6 are located in the western zone, 8 are in eastern zone and rest 14 are in the central zone. Thus, there are 23 sugar factories which are functional in Uttar Pradesh in the co-operative sector having a total crushing capacity of 60,000 TCD [2].

During harvesting season sugarcane is used in the sugar making process. Bagasse is the remaining crushed sugarcane stalk after the juice extraction and is used in sugar mills as fuel to generate electricity and eventually emitted from chimney in the form of fly ash [3]. Burning of bagasse also leads to the emission of many gaseous pollutants and particles into the environment which has an adverse impact on the plantation and health of neighbouring residents [4].

The particles released from sugar mills have similar properties to the particles emitted from combustion and fuel burning. Organic carbon aerosols discharged during the combustion process consist of various compounds, out of which those having three or more fused aromatic rings are polycyclic aromatic hydrocarbons (PAHs) [5]. There are basically two sources of PAHs emission in the atmosphere: natural and anthropogenic. As estimated, the total global atmospheric emission of PAHs is $520 \mathrm{Gg} /$ year comprising of biofuel (58\%), wildfire $(17.0 \%)$, consumer product usage (7\%), traffic oil (5\%) and domestic coal $(4 \%)$ as the major sources in 2004 [6].

In general, the information is limited regarding pollution caused by the burning of sugarcane and its impact on flora and fauna; even if available most of it relates to plantations of sugarcane in Brazil. Previous research has reported the existence of PAHs in various sugarcane products. Sugarcane juice is the main source of benzo(b)fluoranthene, benzo(a)pyrene, Benzo(a)anthracene, and benzo(k) fluoranthene. Burning of sugarcane during the harvest season contributes towards increased levels of PAHs. Different types of PAHs such as dibenz[a,h]anthracene, benz[a]anthracene, benzo[k]fluoranthene benzo[b]fluoranthene and benzo[a]-pyrene have been reported in Cachaca, an alcoholic beverage common in Brazil.

Studies suggest that PAHs contamination in cane sugar is the result of the burning of sugarcane during harvest season and residues of PAHs in final products depend on the processing and refining processes [7]. Sugarcane burning leads to the formation of fly soot which itself is a source of a large number of PAHs [8]. Along with the PAHs, sugarcane fly ash is also the major source of various elements and Elemental analysis can be done by EDXRF technique [9]. 
PAHs have various health effects on human beings; chronic effect includes decreased immune function, kidney and liver damage (e.g., jaundice), cataracts, breathing problems while acute health effects include nausea, diarrhea, vomiting, and eye irritation. Naphthalene, $\mathrm{BaP}$, and benzo (a) anthracene exposed experimental animals show embryotoxic effects [6]. Previous studies have shown that PAHs induce intracellular ROS through intracellular aldo-keto reductase activity which in turn converts $\mathrm{PAH}$-metabolites to $\mathrm{PAH}$-o-quinones which are strong electron acceptors [10].

In this study, we measured the concentration of PAHs in fly ash of sugarcane bagasse and investigated their effects on the cell line (HeLa). Cell viability, generation of reactive oxygen species and DNA damage at various concentrations were studied. Studies done by Mackay et al. show that two and three-ring PAHs have the highest water solubility and are cytotoxic in nature [11]. In a risk assessment conducted for PAHs, naphthalene was found to be a harmful compound due to its direct cytotoxic action [12]. Therefore, among all PAHs Benzo (a)pyrene $(\mathrm{BaP})$ and Naphthalene (Nap) were used as positive control.

\section{Materials and Methods}

\subsection{Standards and Reagents}

Methanol and dichloromethane (HPLC grade) were purchased from Fisher Scientific, USA. MTT[3-(4,5-dimethythiazoyl-2-yl) 2,5-diphenyl tetrazolium bromide], low melting point agarose, dimethyl sulfoxide (DMSO), Ethidium Bromide (EtBr), Analytical standards of a mixture of 16 PAHs, and standards of Benzo(a)pyrene and Naphthalene were purchased from Sigma Aldrich Co., USA. Dulbecco's modified Eagle's medium (DMEM), fetal calf serum and IX Penstrep antibiotic solution were purchased from HiMedia, India. All the remaining chemicals were bought from a local chemical supplier.

\subsection{Sampling}

Sugarcane fly ash sampling was done from Kisan Sahkari Chini Mill of Bisalpur (Figure 1), located in Bareilly, western Uttar Pradesh, India in the month of February 2015. It was established in 1977-78 and its capacity is 2750 TCD (Tones of Cane per day). Its total Cane Area is 9549 hectare [2]. Bisalpur is located at $28.3^{\circ} \mathrm{N} 79.8^{\circ} \mathrm{E}$. It has an average altitude of 156 meters $(512 \mathrm{ft})$. Fly ash samples were collected randomly from the soil surface within a distance of 15 $20 \mathrm{~m}$ from the sugar mill chimney which was further mixed to form a composite sample. After that, the sample was wrapped in an aluminum foil then sealed in pre-coded zip-loc polyethylene bags for carrying to the laboratory. Before processing, undesirable fractions of coarser particles were removed from the samples and then samples were kept in desiccators to avoid moisture.

\subsection{Sample Preparation and Clean up Procedure}

Sample preparation was done as per the method described by Sun et al., 1998 


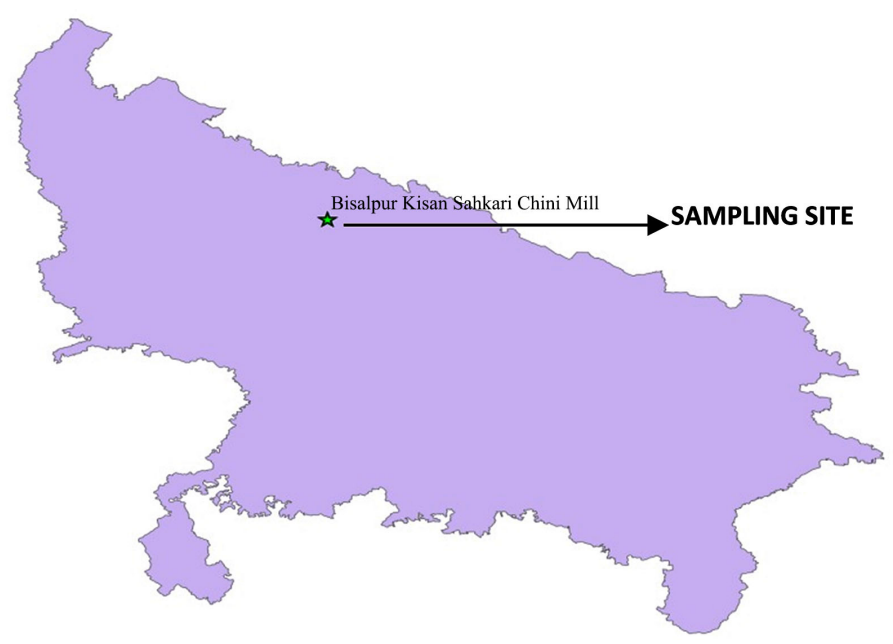

Figure 1. Map Showing Sampling Site Bisalpur Kisan Sahkari Chini near Pilibhit district of Uttar Pradesh, India.

[13]. Extraction was done by ultrasonication method followed by solid phase extraction (SPE) clean-up. In the ultrasonication method, $10 \mathrm{ml}$ dichloroform (DCM) containing $1 \mathrm{~g}$ of fly ash sample was sonicated for 30 minutes. The sample was centrifuged at 12,000 rpm for $5 \mathrm{~min}$ and the supernatant was collected. The same procedure was repeated again by addition of $10 \mathrm{ml}$ of fresh DCM. Finally, the sample was filtered through $90 \mathrm{~mm} \mathrm{GF/C} \mathrm{glass} \mathrm{microfiber} \mathrm{filter} \mathrm{paper}$ (Whatman International, UK). Clean up the procedure of the sample was done by the protocol described by Zamperlini et al., 2000 [14]. Silica column was loaded by $5 \mathrm{ml}$ of fly ash sample. Additional $5 \mathrm{ml}$ methylene chloride was loaded and an aliquot was collected and concentrated to $1 \mathrm{ml}$ under $\mathrm{N}_{2}$ stream and stored in GC vials for further analysis by GC-FID.

\subsection{GC-FID Condition}

Fly ash samples were further identified and quantified by running the samples along with the three different dilutions of standards $100 \mu \mathrm{l}, 500 \mu \mathrm{l}$ and $1000 \mu \mathrm{l}$ made in Dichloroform: Methanol (1:1). GC flame ionization detection (FID) was performed with a Shimadzu GC-2010 gas chromatograph using a capillary column equity 5 ( $30 \mathrm{~m} \times 0.25 \mathrm{~mm}$ I.D., $0.50 \mu \mathrm{m}$ film thickness). Temperature programming was $130^{\circ} \mathrm{C}\left(2 \mathrm{~min}\right.$.) to $260^{\circ} \mathrm{C}$ at the rate of $3^{\circ} \mathrm{C} \mathrm{min}^{-1}(15 \mathrm{~min}$.) total run time was $60.33 \mathrm{~min}$. The Injector temperature was $200^{\circ} \mathrm{C}$ in split mode (auto-injector; $1 \mu \mathrm{l}$ was injected). The detector temperature was $261^{\circ} \mathrm{C}$. Hydrogen was utilized as carrier gas having a flow rate of $40 \mathrm{ml} \cdot \mathrm{min}^{-1}$. Nitrogen/air was utilized as makeup gas having the flow rate of $27.5 \mathrm{ml} \cdot \mathrm{min}^{-1}$ and $400.0 \mathrm{ml} \cdot \mathrm{min}^{-1}$ respectively.

\subsection{Sample Preparation for EDXRF}

Fly ash samples were grinded in mortar and pestle to make a homogeneous fine powder. Fly ash sample was mixed with boric acid (as a supporter base) and then 
by applying 10 tons pressure on the sample, pressed powder samples were prepared. The elemental concentration was evaluated in $1 \mathrm{~g}$ sample using energy dispersive X-ray fluorescence (EDXRF) spectroscopy (Epsilon5 PANalytical) [15].

\subsection{Cell Line and Culture Conditions}

HeLa cells were obtained from National Centre for Cell Science (NCCS), Pune. Adherent cells were cultured in sterile plastic flasks (Corning; Thermo Fisher Scientific, Courtaboeuf France), in Dulbecco's Modified Eagle's medium (DMEM) with Earle's salts, containing: 5\% Fetal Bovine Serum (FBS), 1\% L-L-glutamine $(200 \mathrm{mM}), 1 \%$ penicillin $(10,000 \mathrm{IU} / \mathrm{mL})$, and $1 \%$ streptomycin $(100 \mathrm{mg} / \mathrm{mL})$ (Invitrogen). The constant density of cells $\left(10^{5}\right.$ cells $\left.\cdot \mathrm{ml}^{-1}\right)$ was transferred to 96-well plates used for culturing cells. After that, the different dosage of BaP, Nap and fly ash samples namely 5 ppb, $10 \mathrm{ppb}, 50 \mathrm{ppb}$, and $100 \mathrm{ppb}$ respectively were added to the wells and the plates were incubated for 24 hours at $37^{\circ} \mathrm{C}$. Among eight PAHs, identified in our sample, Benzo (a)pyrene (BaP) and Naphthalene (Nap) were used as positive control. Nap is present in maximum concentration among low molecular weight PAHs, whereas $\mathrm{BaP}$ is a known potent carcinogen. To substitute the supplements, $90 \mu \mathrm{l}$ freshly prepared medium and $20 \mu \mathrm{l}$ MTT ( $5 \mathrm{mg} \cdot \mathrm{ml}^{-1}$ in $7.4 \mathrm{pH}$ of Phosphate Buffer Saline (PBS)) solution were added and incubated for next $4 \mathrm{~h}$ in a chamber with humidity and temperature maintained at $5 \% \mathrm{CO}_{2}$ and $37^{\circ} \mathrm{C}$ respectively. Viable cellular reduction of MTT in each well produced the formazan crystals, which dissolved in sterile DMSO $(100 \mu \mathrm{l})$ by incubation at $37^{\circ} \mathrm{C}$ for $30 \mathrm{~min}$. ELISA reader (SpectraMax M2; Molecular Devices, Sunnydale, CA) at $570 \mathrm{~nm}$ filter quantified absorptions (Optical Density; OD). The relative cell viability (\%) with respect to control (cells without treatment) was estimated as Cellular viability $(\%)=(1-$ OD treated@570nm/OD control@570 nm)×100\% [16].

\subsection{Comet Assay}

After treatment of cells with BaP, Nap and fly ash samples for $24 \mathrm{~h}$, harvesting and fixation of cells using 1:3 glacial acetic acid/methanol was done and then finally the cells were washed with PBS. Comet assay (single cell gel electrophoresis) was employed to ascertain the damage in DNA. Single cell gel electrophoresis was carried out according to the protocol described by Meena, R. \& Paulraj, R. [15]. In brief, microscopic slides were coated with $0.5 \%$ agarose and $10 \mu \mathrm{l}$ single cell suspensions of treated cells were implanted in the coated layer of agarose. The prepared slides were dipped in a jar filled with cold lysis solution (2.5M NaCl, $100 \mathrm{mM}$ EDTA disodium salt, $1 \%$ Triton $\mathrm{X}, 10 \mathrm{mM}$ Tris $\mathrm{HCl}$, $\mathrm{pH}-10)$ and after that were incubated at $4^{\circ} \mathrm{C}$ for two hours. In order to enable unwinding of DNA, the slides were immersed in electrophoresis buffer $(75 \mathrm{mM}$ $\mathrm{NaOH}, 1$ mM EDTA, $\mathrm{pH}>12$ ) and left for 20 minutes. After that, electrophoresis was carried out at $25 \mathrm{~V}, 300 \mathrm{~mA}$ for $20 \mathrm{~min}$. DNA present in each cell was 
neutralized with $0.4 \mathrm{M}$ Tris buffer ( $\mathrm{pH}$ 7.5) and then stained using ethidium bromide. Cellular DNA damage in cells was observed under the fluorescence microscope (Carl Zeiss, Germany). Slides were prepared for different groups and overall 50 cells from each slide were chosen in a non-specific way for further analysis. Evaluation of results was done using Comet IV software (Perceptive Instruments Ltd, UK).

\subsection{Reactive Oxygen Species (ROS)}

2',7'Dichlorofluorescein-diacetate (DCFHDA) dye was used to measure the generation of intracellular ROS (reactive oxygen species) generated in HeLa cells. To measure the intracellular ROS being generated in separate cells, $5 \times 10^{5}$ cells were seeded over coverslip in 6-plated well and incubated overnight for allowing the attachment. Following day, cells were treated with fresh media containing $100 \mathrm{ppb}$ of BaP, Nap and fly ash. Cells were left for incubation for $4 \mathrm{hrs}$ at $37^{\circ} \mathrm{C}$. On completion of the incubation period, the coverslip was removed from the culture plate and was stained with $40 \mu \mathrm{M}$ with DCFHDA for about $30 \mathrm{~min}$. Surplus dye was cleansed-off using 1X PBS. Coverslip was fixed on a glass slide and was observed under a fluorescence microscope (Nikon ECLIPSE TiE, Tokyo, Japan) [16].

\subsection{Statistical Analysis}

Statistical analysis was done using Graph pad prism 5.03. Data were expressed as mean $\pm \mathrm{SD}$, statistical analysis was done using two-way ANOVA and Bonferroni post tests. The $\mathrm{p}$ values $<0.01$ and $\mathrm{p}<0.001$ were considered significant with respect to their control counterpart. All in vitro experimental assays were performed in triplicates.

\section{Results and Discussion}

\subsection{Identification and Quantification of PAHs}

PAHs are semi-volatile compounds having two or more aromatic rings. Burning of bagasse in the boiler leads to fly ash formation. Further identification and quantification of fly ash samples were done by GC-FID in split mode. Figure 2(a) and Figure 2(b) show the chromatogram of standard and PAHs present in the fly ash samples, where the labeled peak represents PAH. The Chromatographic separations of Retention time (Rt) of standards and samples are shown in Table 1 and Table 2. The concentration of each PAHs present in the fly ash sample was calculated from the corresponding calibration curve. The GC-FID result shows that fly ash sample contains different PAHs i.e. Naphthalene (Rt -10.165), Acenaphthene (Rt20.022), Benzo(a)anthracene (Rt26.878), Chrysene (Rt 31.449), Benzo (a)pyrene (Rt 35.067), Dibenz(a,h)anthracene (Rt 41.057), Benzo(g,h,i)perylene (Rt 41.806), Indeno(1,2,3-CD) pyrene (Rt 43.631) and their concentration was found to be $42.94 \mu \mathrm{g} / \mathrm{kg}, 6.16 \mu \mathrm{g} / \mathrm{kg}, 53.24 \mu \mathrm{g} / \mathrm{kg}, 5.82 \mu \mathrm{g} / \mathrm{kg}$, $386.21 \mu \mathrm{g} / \mathrm{kg}, 3.89 \mu \mathrm{g} / \mathrm{kg}, 894.69 \mu \mathrm{g} / \mathrm{kg}$ and $5.12 \mu \mathrm{g} / \mathrm{kg}$ respectively. 


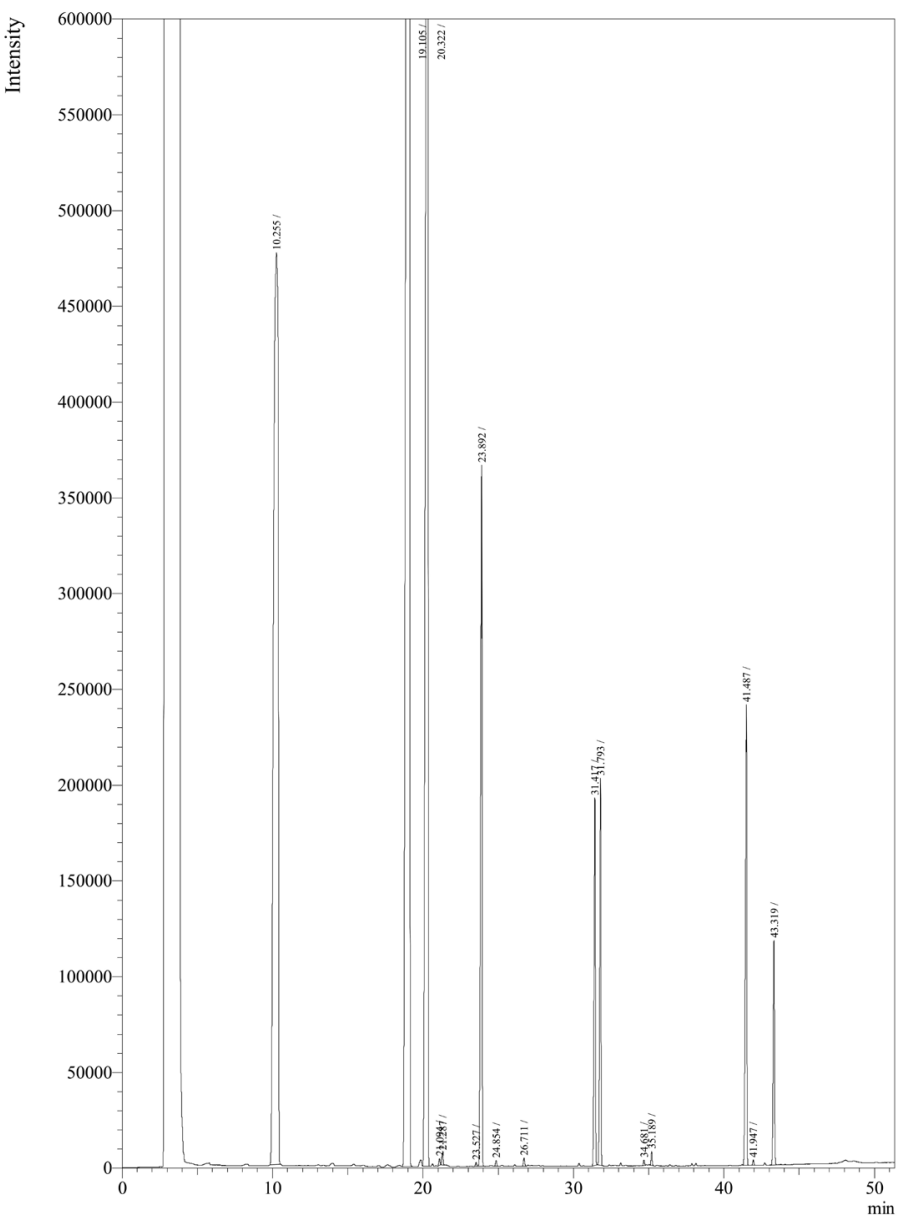

(a)

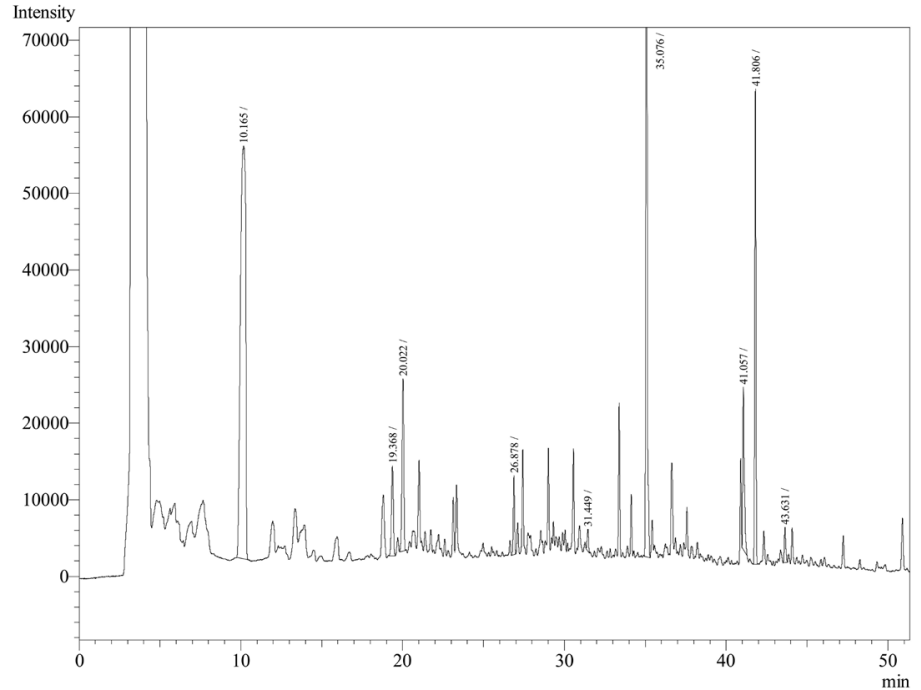

(b)

Figure 2. (a) GC-chromatogram of 16 USEPA PAHs standard. In chromatogram y-axis represent Intensity of peaks whereas $\mathrm{x}$-axis represents Retention times (min) of the corresponding PAHs. (b) GC-chromatogram of sugarcane fly ash sample. In chromatogram $\mathrm{y}$-axis represent Intensity of peaks whereas $\mathrm{x}$-axis represents Retention times (min) of the corresponding PAHs. 
Table 1. Retention time (Rt), area and peak height of PAHs standard.

\begin{tabular}{|c|c|c|c|c|c|c|}
\hline Peaks & $\mathrm{PAHs}$ & $\begin{array}{c}\text { Rt of } \\
\text { standard }\end{array}$ & Area & Area \% & Height & Height \% \\
\hline 1 & Naphthalene & 10.255 & $10,287,158$ & 18.96 & 476,419 & 9.81 \\
\hline 2 & Acenapthylene & 19.105 & $24,508,532$ & 45.16 & $1,945,266$ & 40.06 \\
\hline 3 & Acenaphthene & 20.322 & $12,267,041$ & 22.60 & $1,285,391$ & 26.48 \\
\hline 4 & Fluorene & 21.094 & 20,051 & 0.03 & 3459 & 0.07 \\
\hline 5 & Phenanthrene & 21.287 & 38,180 & 0.07 & 6233 & 0.13 \\
\hline 6 & Anthracene & 23.527 & 11,553 & 0.02 & 2115 & 0.04 \\
\hline 7 & Fluoranthene & 23.892 & $2,490,324$ & 4.59 & 365,799 & 7.53 \\
\hline 8 & Pyrene & 24.854 & 17,032 & 0.03 & 2965 & 0.06 \\
\hline 9 & Benzo(a)anthracene & 26.711 & 23,577 & 0.04 & 4101 & 0.08 \\
\hline 10 & chrysene & 31.417 & $1,142,445$ & 2.11 & 191,516 & 3.94 \\
\hline 11 & Benzo(b)fluoranthene & 31.793 & $1,137,318$ & 2.10 & 201,990 & 4.16 \\
\hline 12 & Benzo(k)fluoranthene & 34.681 & 13,981 & 0.02 & 2712 & 0.05 \\
\hline 13 & Benzo(a)pyrene & 35.189 & 34,577 & 0.06 & 7150 & 0.15 \\
\hline 14 & Dibenz(a,h)anthracene & 41.487 & $1,557,038$ & 2.87 & 239,857 & 4.94 \\
\hline 15 & Benzo(g,h,i)perylene & 41.947 & 13,154 & 0.02 & 2643 & 0.05 \\
\hline 16 & Indeno $(1,2,3-C D)$ & 43.19 & 702,612 & 1.29 & 117,120 & 2.41 \\
\hline
\end{tabular}

Table 2. Shows retention time, area and peak height of Sugarcane fly ash sample.

\begin{tabular}{ccccccc}
\hline \multirow{2}{*}{ Peaks } & PAHs & $\begin{array}{c}\text { RT of } \\
\text { sample }\end{array}$ & Area & Area \% & Height & Height \% \\
\hline 1 & Naphthalene & 10.165 & $1,209,641$ & 44.43 & 53,905 & 17.15 \\
2 & Acenaphthene & 20.022 & 173,329 & 6.37 & 22,496 & 7.16 \\
3 & Benzo(a)anthracene & 26.878 & 54,725 & 2.01 & 10,260 & 3.26 \\
4 & Chrysene & 31.449 & 16,196 & 0.59 & 2828 & 0.90 \\
5 & Benzo(a)pyrene & 35.067 & 684,128 & 25.13 & 125,329 & 39.87 \\
6 & Dibenz(a,h)anthracene & 41.057 & 142,086 & 5.21 & 21,149 & 6.73 \\
7 & Benzo(g,h,i)perylene & 41.806 & 318,556 & 11.70 & 62,036 & 19.73 \\
8 & Indeno(1,2,3-CD) & 43.631 & 28,980 & 1.06 & 4601 & 1.46 \\
\hline
\end{tabular}

Present study suggests that sugarcane fly ash sample is a major source of eight PAHs (namely, Naphthalene, Acenaphthene, Benzo(a)anthracene, chrysene, Benzo(a)pyrene, Indeno(1,2,3-cd)pyrene, Dibenzo(a,h)anthracene, and Benzo(g,h,i)perylene out of 16 EPA priority pollutants. The previous study by Zamperlini et al. identified the PAHs in sugarcane soot having mutagenic and carcinogenic properties [8]. The concentration of PAHs and its maximum allowable concentration (MAC) in soil and water have been shown in Table 3. Among them, $\operatorname{Benzo}(\mathrm{g}, \mathrm{h}, \mathrm{i})$ perylene was found to be having the highest concentration $894.69 \mu \mathrm{g} / \mathrm{kg}$ yet its concentration was less than the maximum allowable con- 
centration in water $3000 \mu \mathrm{g} / \mathrm{kg}$ and soil $3000 \mu \mathrm{g} / \mathrm{kg}$ both. Vacha et al. have reported that in spite of degradation processes in the soil environment (photodegradation, microbial activity etc.) benzo(ghi)perylene are persistent PAHs in the soil [17]. The concentration of Benzo(a)pyrene in fly ash sample was 386.21 $\mu \mathrm{g} / \mathrm{kg}$ which exceeds maximum allowable concentration in both water and soil $5 \mu \mathrm{g} / \mathrm{kg}$ and $300 \mu \mathrm{g} / \mathrm{kg}$ respectively. Our results are in line with the earlier report of Mugica-Alvarez et al. who mentioned that using bagasse as fuel in sugar mill contributes to the significant level of heavy PAHs [4]. The concentration of Benzo(a)anthracene $(53.24 \mu \mathrm{g} / \mathrm{kg})$ exceeds its MAC in water $(5 \mu \mathrm{g} / \mathrm{kg})$. Meanwhile, Naphthalene, Acenaphthene, Chrysene, Indeno(1,2,3-cd)pyrene and Dibenz(a,h)anthracene concentrations in fly ash sample were less than their MAC in water and soil. Previous studies have shown the presence of PAHs in various sugarcane products like sugarcane juice [7] and sugarcane soot [8].

\subsection{ED XRF}

The Inorganic compounds present in sugarcane fly ash were analyzed by EDXRF and the result shows that $\mathrm{SiO}_{2}$ is having the maximum concentration (79\%) (Table 4). Our results align with Baharudin and Santhanam who have reported that $\mathrm{SiO}_{2}$ is the major component in sugarcane which constitutes $70.97 \%$ of sugarcane [18]. The silica content in bagasse varies according to the surrounding environment, nature of the soil, harvesting period and other processes involved [19]. Other elements i.e. phosphorus, magnesium, potassium, iron, sodium, and titanium oxide were present in decreasing order where manganese oxide was found to be in least concentration. Furthermore, our findings are similar with Dogan et al. who mentioned that fly ash obtained from thermal power plants constitutes $90 \%$ of oxides of $\mathrm{Si}, \mathrm{Al}, \mathrm{Fe}$ and $\mathrm{Ca}$ that form the major component of it $[20]$.

Table 5 shows elemental abundance in sugarcane fly ash which was found to be in order of $\mathrm{S}>\mathrm{Ba}>\mathrm{Cl}>\mathrm{Zn}>\mathrm{Sr}>\mathrm{W}>\mathrm{ZrCu}>\mathrm{Rb}>\mathrm{Pb}>$ As. This order indicates that sulfur is present in maximum concentration $4880 \mathrm{ppm}$ followed by $\mathrm{Ba}, \mathrm{Cl}$, and $\mathrm{Zn}$ having concentration of $722.606 \mathrm{ppm}, 411.358 \mathrm{ppm}, 391.326 \mathrm{ppm}$ respectively; whereas tungsten (190.867), zirconium (95.148) copper (82.765), all transitional elements rubidium (79.285), and an alkaline metal are present in moderate concentration and lead and arsenic are present in the least concentration $6.120 \mathrm{ppm}$ and $1.443 \mathrm{ppm}$ respectively. Our results are in alignment with the previous report by Malik et al. who have shown that fly ash obtained from coal-fired thermal power plants has a higher concentration of $\mathrm{Ba}$, intermediate concentration of $\mathrm{Cu}$ and $\mathrm{Rb}$ and least concentration of $\mathrm{As}$ and $\mathrm{Pb}$ [21]. Previous study has shown that fly ash generated from the coal-fired power station is a source of highly toxic metals like $\mathrm{As}, \mathrm{Cd}, \mathrm{Pb}$, etc. in addition to the metals that are crucial for health but are present in trace amount. A similar finding has been found in this study also which shows the presence of $\mathrm{As}, \mathrm{Pb}, \mathrm{Rb}, \mathrm{Cu}$, etc and other elements that are toxic in nature [22]. 
Table 3. Concentration of PAHs in fly ash sample and (MAC), Maximum allowable Concentrations in soil and water.

\begin{tabular}{|c|c|c|c|c|c|}
\hline S. no & PAHs & $\begin{array}{l}\text { No. of } \\
\text { rings }\end{array}$ & $\begin{array}{c}\text { Concentration of } \\
\text { PAHs }(\mu \mathrm{g} / \mathrm{kg})\end{array}$ & $\begin{array}{c}{ }^{*} \mathrm{MAC} \text { in water } \\
(\mu \mathrm{g} / \mathrm{kg})\end{array}$ & $\begin{array}{c}{ }^{*} \text { MAC in soil } \\
(\mu \mathrm{g} / \mathrm{kg})\end{array}$ \\
\hline 1 & Naphthalene & 2 rings & 42.94 & 3000 & 1000 \\
\hline 2 & Acenaphthene & 3 rings & 6.16 & 3000 & 3000 \\
\hline 3 & Benzo(a)anthracene & 4 rings & 53.24 & 5 & 150 \\
\hline 4 & Chrysene & 4 rings & 5.82 & NA & NA \\
\hline 5 & Benzo(a)pyrene & 5 rings & 386.21 & 5 & 300 \\
\hline 6 & Dibenz(a,h)anthracene & 5 rings & 3.89 & 5 & 300 \\
\hline 7 & Benzo(g,h,i)perylene & 6 rings & 894.69 & 3000 & 3000 \\
\hline 8 & Indeno( $1,2,3 \mathrm{CD})$ pyrene & 6 rings & 5.12 & NA & NA \\
\hline
\end{tabular}

*MAC Source: ATSDR, 2006 * NA: Data Not available.

Table 4. Chemical composition (wt\%) of the inorganic fraction in the fly ash by X-ray fluorescence.

\begin{tabular}{ccc}
\hline S.No & Compound & Concentration (\%) \\
\hline 1 & $\mathrm{SiO}_{2}$ & 79.10 \\
2 & $\mathrm{CaO}$ & 5.93 \\
3 & $\mathrm{P}_{2} \mathrm{O}_{5}$ & 5.86 \\
4 & $\mathrm{MgO}$ & 4.63 \\
5 & $\mathrm{~K}_{2} \mathrm{O}$ & 1.89 \\
6 & $\mathrm{Fe}_{2} \mathrm{O}_{3}$ & 1.33 \\
7 & $\mathrm{Na}_{2} \mathrm{O}$ & 0.35 \\
8 & $\mathrm{TiO}_{2}$ & 0.08 \\
9 & $\mathrm{MnO}^{2}$ & 0.06 \\
\hline
\end{tabular}

Table 5. Elemental composition (ppm) of the inorganic fraction in the ash by X-ray fluorescence.

\begin{tabular}{ccc}
\hline S.No & Compound & Concentration $(\mathrm{ppm})$ \\
\hline 1 & $\mathrm{~S}$ & 4880 \\
2 & $\mathrm{Ba}$ & 722.606 \\
3 & $\mathrm{Cl}$ & 411.358 \\
4 & $\mathrm{Zn}$ & 391.326 \\
5 & $\mathrm{Sr}$ & 299.078 \\
6 & $\mathrm{~W}$ & 190.867 \\
7 & $\mathrm{Zr}$ & 95.148 \\
8 & $\mathrm{Cu}$ & 82.765 \\
9 & $\mathrm{Rb}$ & 79.285 \\
10 & $\mathrm{~Pb}$ & 6.120 \\
11 & $\mathrm{As}$ & 1.443 \\
\hline
\end{tabular}




\subsection{Cell Viability}

The cytotoxicity of sugarcane fly ash sample, Benzo(a)pyrene (BaP) and Naphthalene (Nap) samples was evaluated by measuring the cell viability of HeLa cells using MTT assay. Cell viability was found to be decreasing in a dose-dependent manner in pure standards of $\mathrm{BaP}$, Nap, and Fly ash samples. BaP-standard was found to be most cytotoxic as it induces significant $(p<0.001)$ toxicity in all doses except $5 \mathrm{ppb}$ conc. while Nap was found to significantly reduce $(\mathrm{p}<0.001)$ cell viability in high doses i.e. 50 and $100 \mathrm{ppb}$ (Figure 3). Fly ash samples were found to induce significant $(\mathrm{P}<0.001)$ toxicity in 50 and $100 \mathrm{ppb}$ doses as compared to control. The lowest value of LC50 was observed in BaP-treated cells $78.8 \mathrm{ppb}$, which increased to $97.2 \mathrm{ppb}$ in Nap treated cells, while in Fly ash treated cells LC50 was highest at 110.6 ppb. It indicated that Benzo (a) pyrene is more toxic as compared to Naphthalene and fly ash sample at the same concentration. Our results are in line with Raychoudhury \& Kubinski who reported that in general PAHs are cytotoxic in nature and the cytotoxicity of $\mathrm{B}(\mathrm{a}) \mathrm{P}$ is exerted through apoptosis [23]. In contrast to this, Schirmer et al. have shown that naphthalene causes the highest direct cytotoxicity among the 16 studied PAHs due to its increased water solubility and lipophilic properties [12].

\subsection{Generation of Intracellular ROS Levels}

The generation of ROS in HeLa cells has been analysed by DCFCH-DA staining assay. Principally, the intensity of green fluorescence is related with generation of cellular ROS levels. Higher fluorescence intensity corresponds to higher ROS generation in cells. As shown in (Figure 4), treatment with different concentrations of $\mathrm{BaP}, \mathrm{Nap}$, and Fly ash resulted in a dose-dependent increase in the green fluorescence intensity in HeLa cells. The untreated HeLa cancer cells (control) showed a weak and diffused green fluorescence, whereas treated cells with $\mathrm{BaP}$ and Nap exhibited bright fluorescence intensity. Fly ash could induce significant

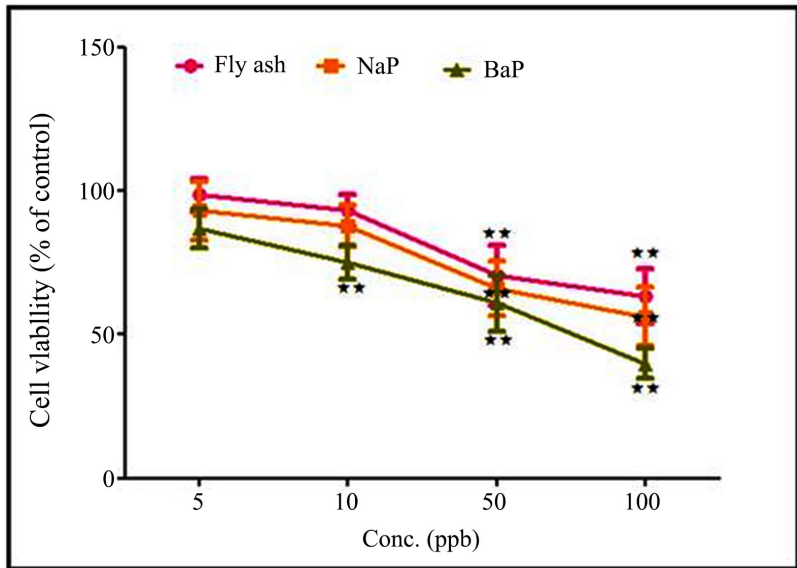

Figure 3. Effect of various concentration of Fly ash sample, $\mathrm{BaP}$ and $\mathrm{NaP}$ on cell viability of HeLa cells by MTT assay (** represents statistically significant at $\mathrm{p}<0.001$ as compare to control). 

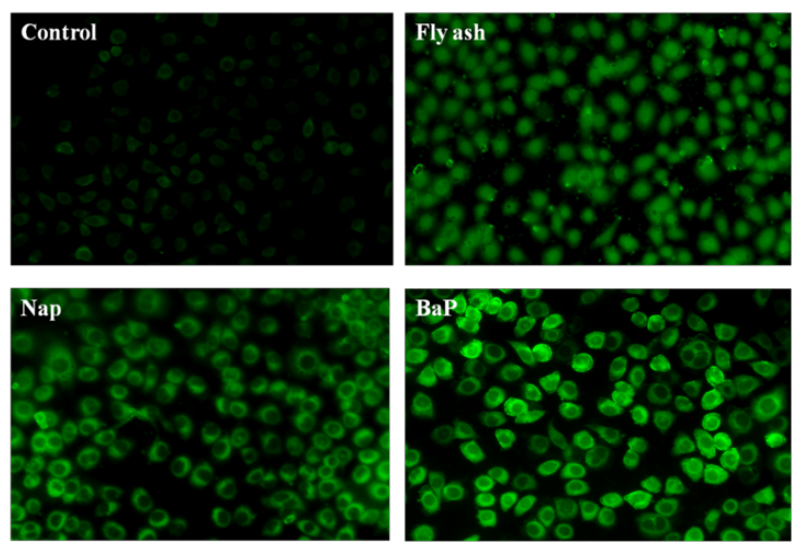

(a)

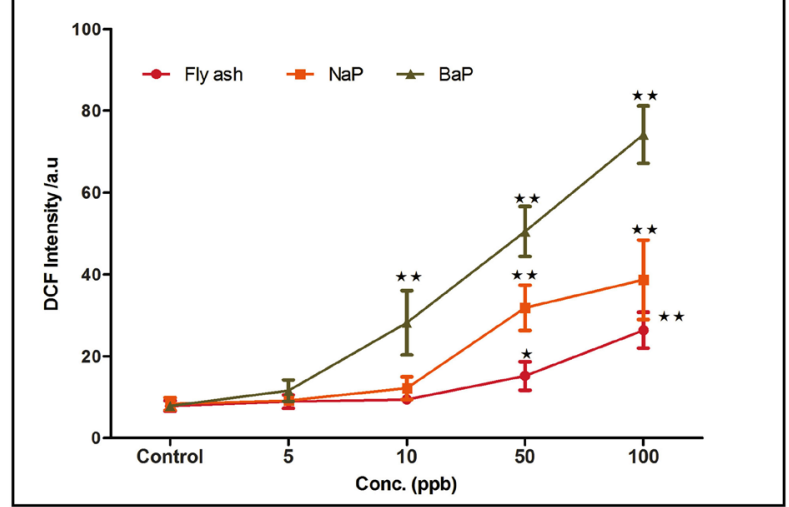

(b)

Figure 4. (a) Fluorescence intensity showing the extent of ROS generation in HeLa cells. (b) Line graph shows the effect of various concentration of Fly ash sample, $\mathrm{BaP}$ and $\mathrm{NaP}$ on ROS intensity of HeLa cells ${ }^{\star *}$ represents statistically significant at $\mathrm{p}<0.001$ as compare to control and ${ }^{\star}$ denotes statistically significant at $\mathrm{p}<0.01$ as compare to their control counterpart).

$(\mathrm{P}<0.001)$ increase in oxidative stress in HeLa cells as compared to its control. ROS level was found to increase in higher doses i.e. 50 and $100 \mathrm{ppb}$. Our positive control samples i.e. Nap and $\mathrm{BaP}$ also showed similar results as florescence intensity was higher in positive groups as compared to fly ash sample which suggests that the underlying reason may be attributed to the presence of PAHs. Significant dose dependent increase in oxidative stress in higher doses was reported which indicates that the higher conc. of PAHs was responsible for inducing these changes. Our results are similar to Wilk et al. [24] who reported that PAHs activate the intracellular ROS accumulation which further leads to oxidative DNA damage. In our study, PAHs were found to induce oxidative stress but the intensity was significantly $(\mathrm{p}<0.001)$ higher in pure PAHs standards (BaP and Nap) as compared to fly ash at same concentration. This may be due to decreased concentration of PAHs in fly ash in comparison to pure standards.

\subsection{DNA Damage}

The DNA Damage induced by fly ash was measured through comet assay. The 
extensive and dose-dependent DNA damage was observed in all three groups. In the cells exposed to $100 \mathrm{ppb} \mathrm{BaP}(145.2 \pm 14.8 \mu \mathrm{m})$, tail length was reported to be around five times higher as compared to the control cells and approximately 1.5-fold higher than Nap treated cells $(101.2 \pm 11.4 \mu \mathrm{m})$ whereas the mean tail length in fly ash sample was found to be 3 fold higher than control. Fly ash sample which has the lower PAHs concentration recorded the lowest value (77.08 \pm 9.2) at $100 \mathrm{ppb}$ concentration as compared to $\mathrm{BaP}$ and Nap treated group. However, a lower concentration (5 ppb) of PAHs did not cause significant changes in tail length in HeLa cells (Figure 5). The tail intensity increased significantly $(\mathrm{P}<$ 0.001 ) approximately 5 -fold in cells treated with $100 \mathrm{ppb}$ of $\mathrm{BaP}$ and Nap in comparison to control. Similarly, fly ash sample induced significant $(\mathrm{P}<0.001)$ DNA damage in cells treated with higher doses (50 \& $100 \mathrm{ppb}$ ). Tail intensity in cells treated with fly ash sample was increased by 3.5 fold. These results show that $\mathrm{BaP}$ and Nap induced higher DNA damage as compared to fly ash sample at the same concentration (100 ppb) while lower concentration (5 ppb) of all three groups did not induce significant DNA damage in HeLa cells (Figure 5).

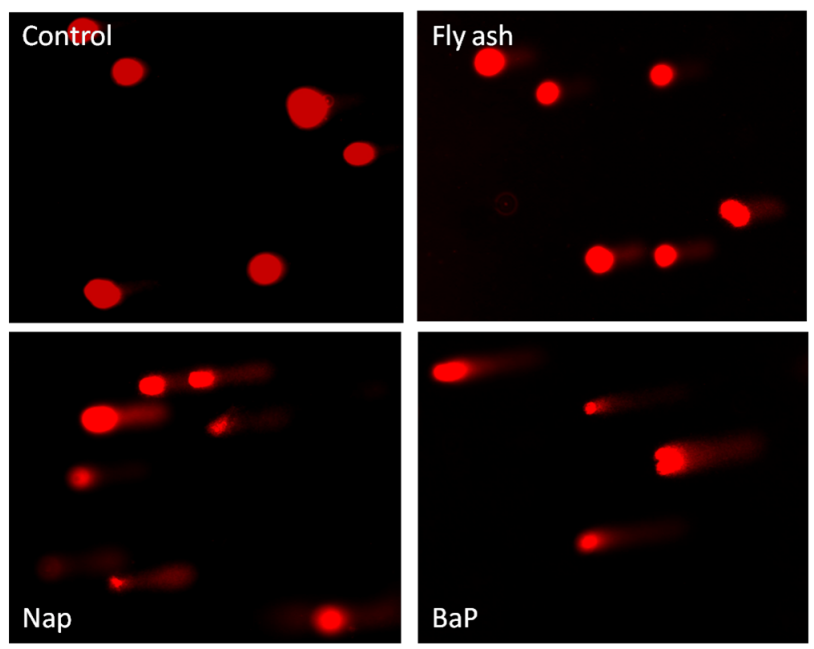

(a)

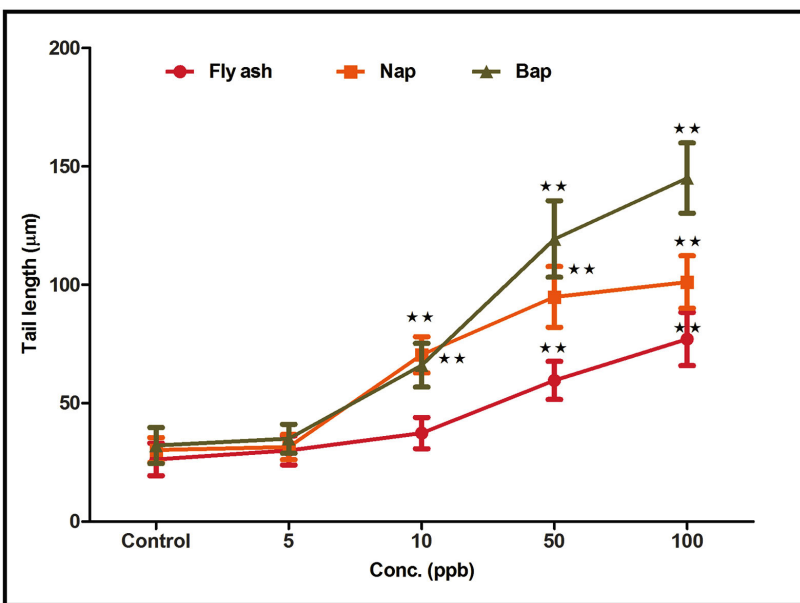

(b) 


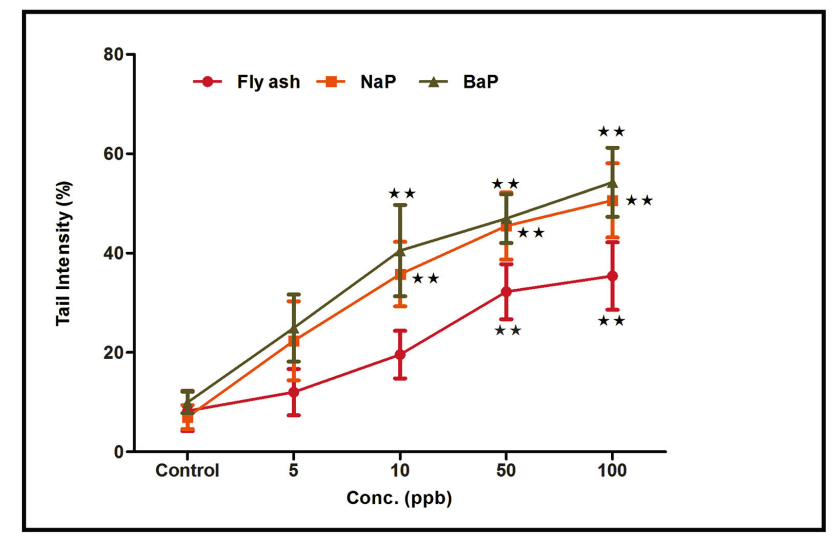

(c)

Figure 5. DNA damage in HeLa cells treated with different doses of Fly ash, BaP and NaP (** represents statistically significant at $\mathrm{p}<0.001$ as compared to control). (a) Images showing comet formation, (b) Line graph displays the level of DNA damage in terms of comet tail length. (c) Line graph displays tail intensity of comet in different groups.

These results illustrate that the intensity of DNA damage was highest in $\mathrm{BaP}$ followed by Nap and Fly ash sample. Our results are in line with Tarantini et al. who performed comet assay of pure $\mathrm{B}(\mathrm{a}) \mathrm{P}$, Nap and samples made by the extraction of particulate matter from air samples collected in an urban peri-industrial site and concluded that toxicity of Nap is less as compared to B(a)P [25]. Our findings are in concurrence with the previous results which reported approximately 3-times enlargement of tail length as compared to control at higher doses of BaP. The intensity of DNA damage was highest in $\mathrm{BaP}$ as compared with other PAHs like fluoranthene, anthracene, pyrene, and phenanthrene [26].

In general, PAHs do not directly induce DNA damage, but are transformed to PAHs metabolites that cause DNA damage through metabolic enzymes and there are 3 major pathways known: the CYP1A1/1B1 and epoxide hydrolase pathway (CYP/EH pathway), CYP peroxidase pathway, and aldo-keto reductases pathway (AKR pathway). Generally, CYPs and other metabolic enzymes mobilized into phenols and catechols metabolize PAHs and quinones resulting in the formation of diol-epoxides, radical cations, or reactive and redox-active o-quinones, all of which may interact with DNA to forms DNA adducts. The reactive metabolites of PAHs may also trigger the development of protein adducts in cells and modify the normal functioning of these proteins [27]. In addition, the metabolites produced by PAHs may initiate increased ROS production which in turn can result in DNA damage, lipid peroxidation or protein denaturation [28]. Marine sediments containing PAHs like benzo[ghi]perylene, indeno[123-cd]pyrene, benzo[k]fluoranthene, benzo[b]fluoranthene, benzo[a]pyrene, dibenzo[ah]anthracene showed dose-dependent effects in MTT and comet assay [29]. Results of comet assay showed that DNA damage was maximum in cells treated with $\mathrm{B}(\mathrm{a}) \mathrm{P}$ followed by other PAHs like fluoranthene, anthracene, pyrene, and phenanthrene [26]. Our results show that Fly ash induces the generation of reactive oxygen species which might cause damage to the 
DNA leading to cell death. In our study, it was reported that the fly ash sample also contains a significant amount of $\mathrm{SiO}_{2}$ and $\mathrm{PAHs}$ which are known to induce DNA damage. Moreover, fly ash was found to induce DNA damage via the oxidative stress in V79 cells in-vitro. The report says that nanosize fly ash and PAHs were found to induce DNA damage which was evaluated through comet assay. Nonetheless, our study is in line with other research which states that the coal and its by-product were observed to induce oxidative stress-dependent DNA damage [30].

\section{Conclusion}

From our findings, it may be concluded that fly ash is an important source of PAHs that are cytotoxic and genotoxic in nature. However, their level of toxicity was less as compared to pure individual standards of PAHs (BaP and Nap) but it suggests that higher concentration of fly ash is deleterious to the environment. Possibly, emission of fly ash from mills may leach down in groundwater and may also get deposited in agricultural soil through which it may get biomagnified in the food chain. Therefore, it may cause deleterious effects to both abiotic and biotic factors of the environment. It will not only affect the surrounding flora and fauna but also workers engaged in Sugarmill. Sugarcane bagasse fly ash causes severe environmental pollution which calls for urgent ways of handling the waste.

\section{Acknowledgements}

The financial assistance provided by the Council of Scientific and Industrial Research (CSIR), New Delhi, India for completion of this research work is duly acknowledged. Fund received from UPE-II is sincerely acknowledged. Author is also thankful to Advanced Instrumentation Research Facility (AIRF), JNU for ED XRF facility and Central Instrumentation Facility (CIF) of School of Environmental Sciences for GC FID facility.

\section{Conflicts of Interest}

The authors declare no conflicts of interest regarding the publication of this paper.

\section{References}

[1] Marotrao, K.P. (2017) Effect of Drip Irrigation on Sugarcane Production: A Case Study. International Journal of Tropical Agriculture, 35, 303-313.

[2] Uttar Pradesh Cooperative Sugar Factories Federation Limited. http://www.upsugarfed.org http://www.upsugarfed.org/index.asp

[3] Srinivasan, R. and Sathiya, K. (2010) Experimental Study on Bagasse Ash in Concrete. International Journal for Service Learning in Engineering, Humanitarian Engineering and Social Entrepreneurship, 5, 60-66. https://doi.org/10.24908/ijsle.v5i2.2992 
[4] Mugica-Alvarez, V., Santiago-de la Rosa, N., Figueroa-Lara, J., Flores-Rodríguez, J., Torres-Rodríguez, M. and Magaña-Reyes, M. (2015) Emissions of PAHs Derived from Sugarcane Burning and Processing in Chiapas and Morelos México. Science of the Total Environment, 527, 474-482. https://doi.org/10.1016/j.scitotenv.2015.04.089

[5] Choi, H., Harrison, R., Komulainen, H. and Delgado, J. (2010) Polycyclic Aromatic Hydrocarbons. WHO Guidelines for Indoor Air Quality: Selected Pollutants. World Health Organization, Geneva, 1-12.

[6] Rengarajan, T., Rajendran, P., Nandakumar, N., Lokeshkumar, B., Rajendran, P. and Nishigaki, I. (2015) Exposure to Polycyclic Aromatic Hydrocarbons with Special Focus on Cancer. Asian Pacific Journal of Tropical Biomedicine, 5, 182-189. https://doi.org/10.1016/S2221-1691(15)30003-4

[7] Tfouni, S.A., Souza, N.G., Neto, M.B., Loredo, I.S., Leme, F.M. and Furlani, R.P. (2009) Polycyclic Aromatic Hydrocarbons (PAHs) in Sugarcane Juice. Food Chemistry, 116, 391-394. https://doi.org/10.1016/j.foodchem.2009.02.040

[8] Zamperlini, G.C.M., Silva, M.R.S. and Vilegas, W. (1997) Identification of Polycyclic Aromatic Hydrocarbons in Sugar Cane Soot by Gas Chromatography-Mass Spectrometry. Chromatographia, 46, 655-663. https://doi.org/10.1007/BF02490527

[9] Cakir, C., Budak, G., Karabulut, A. and Şahin, Y. (2003) Analysis of Trace Elements in Different Three Region Coals in Erzurum (Turkey): A Study Using EDXRF. Journal of Quantitative Spectroscopy and Radiative Transfer, 76, 101-106. https://doi.org/10.1016/S0022-4073(02)00048-1

[10] Park, J.H. and Penning, T.M. (2009) Polyaromatic Hydrocarbons. In: Process-Induced Food Toxicants: Occurrence, Formation, Mitigation, and Health Risks, John Wiley and Sons, Hoboken, 243-282. https://doi.org/10.1002/9780470430101.ch2h

[11] Mackay, D., Shiu, W.Y. and Ma, K.C. (1992) Illustrated Handbook of Physical-Chemical Properties and Environmental Fate for Organic Chemicals. Vol. 2, Lewis Publishers, Chelsea.

[12] Schirmer, K., Dixon, D.G., Greenberg, B.M. and Bols, N.C. (1998) Ability of 16 Priority PAHs to Be Directly Cytotoxic to a Cell Line from the Rainbow Trout Gill. Toxicology, 127, 129-141. https://doi.org/10.1016/S0300-483X(98)00030-4

[13] Sun, F., Littlejohn, D. and Gibson, M.D. (1998) Ultrasonication Extraction and Solid Phase Extraction Clean-Up for Determination of US EPA 16 Priority Pollutant Polycyclic Aromatic Hydrocarbons in Soils by Reversed-Phase Liquid Chromatography with Ultraviolet Absorption Detection. Analytica Chimica Acta, 364, 1-11. https://doi.org/10.1016/S0003-2670(98)00186-X

[14] Zamperlini, G.C., Santiago-Silva, M. and Vilegas, W. (2000) Solid-Phase Extraction of Sugar Cane Soot Extract for Analysis by Gas Chromatography with Flame Ionisation and Mass Spectrometric Detection. Journal of Chromatography A, 889, 281-286. https://doi.org/10.1016/S0021-9673(00)00291-0

[15] Meena, R. and Paulraj, R. (2012) Oxidative Stress Mediated Cytotoxicity of $\mathrm{TiO}_{2}$ Nano Anatase in Liver and Kidney of Wistar Rat. Toxicological \& Environmental Chemistry, 94, 146-163. https://doi.org/10.1080/02772248.2011.638441

[16] Meena, R., Kumar, S., Gaharwar, U.S. and Rajamani, P. (2017) PLGA-CTAB Curcumin Nanoparticles: Fabrication, Characterization and Molecular Basis of Anticancer Activity in Triple Negative Breast Cancer Cell Lines (MDA-MB-231 Cells). Biomedicine \& Pharmacotherapy, 94, 944-954. https://doi.org/10.1016/j.biopha.2017.07.151 
[17] Vacha, R., Cechmankova, J. and Skala, J. (2010) Polycyclic Aromatic Hydrocarbons in Soil and Selected Plants. Plant, Soil and Environment, 56, 434-443. https://doi.org/10.17221/7/2010-PSE

[18] Bahurudeen, A. and Santhanam, M. (2015) Influence of Different Processing Methods on the Pozzolanic Performance of Sugarcane Bagasse Ash. Cement and Concrete Composites, 56, 32-45. https://doi.org/10.1016/j.cemconcomp.2014.11.002

[19] Norsuraya, S., Fazlena, H. and Norhasyimi, R. (2016) Sugarcane Bagasse as a Renewable Source of Silica to Synthesize Santa Barbara Amorphous-15 (SBA-15). Procedia Engineering, 148, 839-846. https://doi.org/10.1016/j.proeng.2016.06.627

[20] Dogan, O., Symsek, Ö., Nuhoglu, Y., Kopya, M. and Ertugrul, M. (2001) X-Ray Fluorescence Spectrometry Analysis of Trace Elements in Fly Ash Samples of Kemerköy Thermal Power Plants. Journal of Trace and Microprobe Techniques, 19, 289-295. https://doi.org/10.1081/TMA-100002218

[21] Malik, M., Soni, N.K., Kanagasabapathy, V., Prasad, M.V.R. and Satpathy, K.K. (2016) Characterisation of Fly Ash from Coal Fired Thermal Power Plants Using Energy Dispersive X-Ray Fluorescence Spectrometry. Scientific Reviews and Chemical Communications, 6, 91-101.

[22] Ayanda, O.S., Fatoki, O.S., Adekola, F.A. and Ximba, B.J. (2012) Characterization of Fly Ash Generated from Matla Power Station in Mpumalanga, South Africa. Journal of Chemistry, 9, 1788-1795. https://doi.org/10.1155/2012/451801

[23] Raychoudhury, S.S. and Kubinski, D. (2003) Polycyclic Aromatic Hydrocarbon-Induced Cytotoxicity in Cultured Rat Sertoli Cells Involves Differential Apoptotic Response. Environmental Health Perspectives, 111, 33-38.

https://doi.org/10.1289/ehp.5458

[24] Wilk, A., Waligórski, P., Lassak, A., Vashistha, H., Lirette, D., Tate, D. and Estrada, J.J. (2013) Polycyclic Aromatic Hydrocarbons-Induced ROS Accumulation Enhances Mutagenic Potential of T Antigen from Human Polyomavirus JC. Journal of Cellular Physiology, 228, 2127-2138. https://doi.org/10.1002/jcp.24375

[25] Tarantini, A., Maitre, A., Lefebvre, E., Marques, M., Marie, C., Ravanat, J.L. and Douki, T. (2009) Relative Contribution of DNA Strand Breaks and DNA Adducts to the Genotoxicity of Benzo [a] Pyrene as a Pure Compound and in Complex Mixtures. Mutation Research/Fundamental and Molecular Mechanisms of Mutagenesis, 671, 67-75. https://doi.org/10.1016/j.mrfmmm.2009.08.014

[26] Woo, S., Kim, S., Yum, S., Yim, U.H. and Lee, T.K. (2006) Comet Assay for the Detection of Genotoxicity in Blood Cells of Flounder (Paralichthys olivaceus) Exposed to Sediments and Polycyclic Aromatic Hydrocarbons. Marine Pollution Bulletin, 52, 1768-1775. https://doi.org/10.1016/j.marpolbul.2006.08.027

[27] Berge, G., Mollerup, S., Hewer, A., Phillips, D.H., Eilertsen, E. and Haugen, A. (2004) Role of Estrogen Receptor in Regulation of Polycyclic Aromatic Hydrocarbon Metabolic Activation in Lung. Lung Cancer, 45, 289-297. https://doi.org/10.1016/j.lungcan.2004.02.014

[28] Kwack, S.J. and Lee, B.M. (2000) Correlation between DNA or Protein Adducts and Benzo[a]pyrene Diol Epoxide I-Triglyceride Adduct Detected in Vitro and in Vivo. Carcinogenesis, 21, 629-632. https://doi.org/10.1093/carcin/21.4.629

[29] Yang, F., Zhang, Q., Guo, H. and Zhang, S. (2010) Evaluation of Cytotoxicity, Genotoxicity and Teratogenicity of Marine Sediments from Qingdao Coastal Areas Using in Vitro Fish Cell Assay, Comet Assay and Zebrafish Embryo Test. Toxicology in Vitro, 24, 2003-2011. https://doi.org/10.1016/j.tiv.2010.07.019

[30] Matzenbacher, C.A., Garcia, A.L.H., dos Santos, M.S., Nicolau, C.C., Premoli, S., 
Corrêa, D.S. and Kalkreuth, W. (2017) DNA Damage Induced by Coal Dust, Fly and Bottom Ash from Coal Combustion Evaluated Using the Micronucleus Test and Comet Assay in Vitro. Journal of Hazardous Materials, 324, 781-788.

https://doi.org/10.1016/j.jhazmat.2016.11.062 